\title{
GENDER DIFFERENCE IN UNDERSTANDING AGEING AND RETIREMENT
}

\author{
Nik Osman $\mathrm{NNA}^{1,2}$, Awang $\mathrm{H}^{2}$. \\ ${ }^{1}$ Institute Advanced Studies, University of Malaya, Malaysia \\ ${ }^{2}$ Social Wellbeing Research Centre, University of Malaya, Malaysia
}

\author{
Correspondence: \\ Nik Noor Ainoon Nik Osman \\ Social Wellbeing Research Centre \\ Faculty of Economics and Administration \\ University of Malaya \\ 50603 Kuala Lumpur \\ Email:niknoon@um.edu.my
}

\begin{abstract}
The age-old wisdom is that "women live longer than men". Gender difference in life expectancy is becoming a worldwide phenomenon both in developed and developing countries. The process of ageing may be viewed from the perspectives of physical, psychological, and social-economic wellbeing. We investigated gender difference in understanding ageing in relation to life expectancy, fears relating to diseases and deteriorating economic status, and perceived old age comfort and their preparedness. Data were obtained from an online survey and in-person interview of 518 respondents aged 40 years and older residing in Malaysia, which was based on a convenience sample collected from May 2015 to January 2016. Data were analysed using chisquared tests and multinomial logistic regression. There were varying views between men and women when it came to understanding ageing in relation to life expectancy, fears of ageing, deteriorating economic status and their perception of old age comfort. Women were more optimistic about living longer compared to men but feared more the consequences of old age diseases. In spite of displaying less concern about financial preparedness, women were, however, willing to cut down expenses, while men would prefer longer working hours to ensure a comfortable retirement.
\end{abstract}

Keywords: Gender Difference, Life Expectancy, Ageing, Fear, Financial Comfort

\section{Introduction}

Life expectancy among the elderly has been improving for many decades which is evident from the significantly improving general health status of older persons. This is largely attributable to improved medical care and advances in knowledge of age-associated diseases $(1,2)$.

As a result of increased life expectancy and lowered fertility rates, there has been a rapidly growing population of people aged sixty and older (3). In all the nations, however, both developed and developing, older people face an array of vulnerabilities. Among them are the lack of income, health insecurity and the need for physical care (3), thus making ageing an inescapable issue for everyone. Increasing longevity cannot be assumed to be accompanied by an extended period of good health, as studies have shown little evidence to suggest that older people today are experiencing better health than their parents when they were their age (4).

Longer life expectancy for women as compared to men is a worldwide phenomenon both in industrialised nations and in low-income countries $(5,6)$. In most parts of the world, women live longer by five to seven years. Longevity that contributes to female life expectancy is complex, with multi-factorial traits of genetic, environmental, historical, socio-economic, cultural and geographical origin, as well as a combination of biological and sexual characteristics, social role, lifestyle, life experiences and maternal habits $(6,7)$.

Despite the striking difference in longevity, older women tend to have a more negative self-concept compared to men. A meta-analysis by Pinquart, \& Sörensen in 2001 (8) revealed that women were more disadvantaged with regard to health resources because of their higher morbidity rates, thereby requiring more care, and they spent their later life with illness and disability, and in the loneliness of being widowed (8).

The research found that the thought of loneliness, being unwanted or becoming a burden and dependent upon friends and family members, were some of the reasons that contributed to the fear of ageing in an individual (9). 
Consequently, personal relationship, social networks, social support and practical support of family and friends were important influences in the quality of life, which in turn had a positive influence on the subjective life expectancy of the elderly (10). The reality was if one lived long enough, inevitably, ageing would entail multiple losses, including the loss of work and physical functioning which could significantly reduce health-related quality of life (11). The perception in the general community was that illness was a natural part of growing old, and people should expect to have to live with pain as they grew older (12).

Many had fears about the possibility of developing the long-term complications of chronic illness: cancer, Alzheimer's, diabetes, arthritis and heart diseases which are among the leading causes of morbidity and mortality worldwide (3). The fear of the debilitating consequences of these illnesses (13) was compounded by the associated societal stigma; as in the case of dementia, with the need for the service of a caregiver, and the enormous healthcare cost (14).

Women were also found to be more vulnerable to declining social and economic status in their old age as compared to men due to the higher expenditure of chronic health problems as they aged, thereby resulting in the greater anxiety of their ageing process and the need for stronger intergenerational relations $(14,15)$.

Poor health could undermine relative income security as it reminded older people that they might need to tap into their savings to cope with the expenditure. The situation would be made worse if the income from their social security was insufficient to maintain the standards of living for the elderly, and if caregivers within family members were scarce (16). As Bloom et al. (16) contended, in developed countries, longer lifespan meant a shift in support for the elderly from family members to the state; while in developing countries, families remained pivotal to elder care but longer life spans might disrupt family structures which might lead to a move towards public transfer systems similar to that of developed countries. Thus, there is a need for policies that addressed the changing needs of the elderly during old age (16).

One of the factors that would determine the level of confidence of ageing comfort is financial literacy. Low financial literacy was found to be prevalent among the lower income group and women $(17,18)$; whilst women who displayed higher financial literacy were more likely to plan for their retirement, as seen in cross-country studies covering Malaysia $(19,20,21)$, Europe (22), Australia (23), New Zealand (24), and the United States (25). Evidence suggests that the economic status of the elderly is the most important variable associated with planning for retirement in addition to psychological preparedness and life satisfaction (26).

A financial survey in 2010 (27) on American families, on 2,151 adults, reported that many were increasingly anxious about the financial security of their families, as they planned for the years ahead. The economic crisis of 2008 compelled more people to turn to family members, relatives, friends and community members for financial and caregiving support as they confronted long-term health concerns for themselves and their loved ones. In Malaysia, although an older female shared some similarities with an older male in terms of personal finance matters, they were more likely to be relegated because of a lower education, a less net worth compared to older men and a less attachment to the labour force, thereby making it a challenge to promote the financial well-being of older women (28).

Researchers the world over had observed gender differences in a number of different domains. However, studies on gender difference in understanding ageing had been few. The situations facing males and females could be very different (29) and how they experienced the world around them carried various social and cultural implications (30). Demographic ageing in Malaysia just as elsewhere seemed to skew towards more females, suggesting a feminisation of ageing in the future, with concomitant challenges to family care and costs (29). Adapting from the Genworth National Study (2010), this research investigated the difference between men and women in their perception of ageing and their preparedness in going through the ageing process. In particular, this research studied the life expectancy, most feared disabling diseases and long-term illness, confidence in post-retirement financial adequacy and comfort, and their opinions on various dimensions of ageing and retirement.

\section{Materials and Methods}

We analysed data of a survey through convenience sampling in 2015 of 518 respondents aged 40 years and older, using a self-administered questionnaire, and an in-person interview. The sample consisted of 40 per cent online respondents and 60 per cent personal interviews conducted throughout the country. This was an exploratory study of a nationwide Malaysia Ageing and Retirement Survey launched in early 2018 in which citizens aged 40 years and older were the target respondents. Respondents in this study were informed before the data collection that by answering the questionnaire, they would have given their consent to participate in the survey and that no incentive would be given for their participation. The questionnaire was adapted from the 2010 Genworth Financial Survey (27) and was in both English and Malay. Personal background, employment, years expected to live, the greatest fear of old age and long-term illness, confidence in post-retirement comfort and attitudes towards various dimensions of ageing and retirement were asked. A five-point Likert scale was used for the question concerning confidence on post-retirement comfort, and there were nine statements related to various dimensions of ageing and retirement. The Cronbach Alpha for these statements was 0.746 . 


\section{Results}

\section{Respondents' demographic and employment profile}

The gender ratio for male and female respondents was 45:55. The mean age was 51.8 years, and for both genders, a high proportion of the respondents were younger than 60 ( $80.2 \%$ male; $88.0 \%$ female), and the majority of them were from urban areas. Data indicated that about $95 \%$ of the respondents had ever worked while about 74\% were still working at the time of the study. The majority of the male respondents (66\%) were in the professional/ management category as compared to 55 per cent of the females. Regarding ethnicity, $66 \%$ of the total sample were Malays, followed by the Chinese $21 \%$, and the other ethnic groups $13 \%$ (Table 1 ).

Table 1: Respondents' demographic and employment profile

\begin{tabular}{|c|c|c|c|c|c|c|c|}
\hline & \multirow[t]{2}{*}{ Variable } & \multicolumn{2}{|c|}{ Total } & \multicolumn{2}{|c|}{ Male } & \multicolumn{2}{|c|}{ Female } \\
\hline & & $(\mathrm{N}=518)$ & Percent & Frequency & Percent & Frequency & Percent \\
\hline \multirow[t]{3}{*}{ Age } & $40-49$ & 243 & 47.1 & 105 & 45.3 & 138 & 48.6 \\
\hline & $50-59$ & 193 & 37.4 & 81 & 34.9 & 112 & 39.4 \\
\hline & 60 and above & 80 & 15.5 & 46 & 19.8 & 34 & 12.0 \\
\hline \multirow[t]{3}{*}{ Ethnicity } & Malay & 340 & 65.6 & 149 & 63.9 & 191 & 67.0 \\
\hline & Chinese & 108 & 20.9 & 48 & 20.6 & 60 & 21.1 \\
\hline & Others & 70 & 13.5 & 36 & 15.5 & 34 & 11.9 \\
\hline \multirow[t]{2}{*}{ Locality } & Urban & 367 & 71.0 & 176 & 75.5 & 191 & 67.3 \\
\hline & Rural & 150 & 29.0 & 57 & 24.5 & 93 & 32.7 \\
\hline \multirow{2}{*}{$\begin{array}{l}\text { Have Worked } \\
\text { /Never }\end{array}$} & Yes & 494 & 95.4 & 230 & 98.7 & 264 & 92.6 \\
\hline & No & 24 & 4.6 & 3 & 1.3 & 21 & 7.4 \\
\hline \multirow{3}{*}{$\begin{array}{l}\text { Current } \\
\text { Employment } \\
\text { Status }\end{array}$} & Still working & 381 & 73.6 & 174 & 74.7 & 207 & 72.6 \\
\hline & $\begin{array}{l}\text { Self-employed/own } \\
\text { account worker }\end{array}$ & 61 & 11.7 & 30 & 12.9 & 31 & 10.9 \\
\hline & Not working & 76 & 14.7 & 29 & 12.4 & 47 & 16.5 \\
\hline \multirow[t]{3}{*}{$\begin{array}{l}\text { Employment } \\
\text { Category }\end{array}$} & $\begin{array}{l}\text { Professional/ } \\
\text { Management }\end{array}$ & 312 & 60.5 & 154 & 66.1 & 158 & 55.4 \\
\hline & Other & 206 & 39.5 & 79 & 33.9 & 127 & 44.6 \\
\hline & Total & 518 & 100.0 & 233 & 100.0 & 285 & 100.0 \\
\hline
\end{tabular}

\section{Opinions on life expectancy}

When asked how many years past 60 could a man and woman expect to live, Table 2 revealed that male respondents felt that a man could live up to 16.2 years more while a woman could live up to 18 more years. Female respondents, on the other hand, felt that a man could live up to 16.4 years while a woman could live up to 19 more years. However, both genders were of the opinion that most people in Malaysia would like to live up to the age of slightly above 81 years old.

Table 2: Opinions on life expectancy

\begin{tabular}{llll}
\hline Variable & Male & Female & T-statistics \\
\hline Man aged 60 & 16.24 & 16.42 & -0.243 \\
Woman aged 60 & 18.04 & 19.04 & -1.182 \\
$\begin{array}{l}\text { Number of years } \\
\text { most people in }\end{array}$ & 81.04 & 81.43 & -0.462 \\
$\begin{array}{l}\text { Malaysia would } \\
\text { like to live }\end{array}$ & & & \\
\hline
\end{tabular}

\section{Biggest worries and most feared disabling disease and long-term illness}

As indicated in Table 3, the majority of the male and female respondents stated that their biggest concern and worry in life was financial; males (42.9\%) and females (39.3\%) mostly citing reasons of rising cost of living. Health was their number two concern, though females seemed to be more worried (35.1\%) as compared to males (28.8\%). The most feared disease for males was cancer, followed by heart and cardiovascular diseases and Alzheimer's. Regarding fear, there was no significant difference between male and female responses, except for heart disease where a significantly larger number of men (59\%), as compared to women (40\%), stated that it was the most feared after cancer. For both genders, their greatest fears regarding having long-term illnesses were being a burden to their family (male: $62.7 \%$; female: $68.1 \%$ ) and using up their savings (13.7\%). 
Table 3: Biggest worries and most feared disabling disease and long term illness

\begin{tabular}{|l|l|c|c|c|}
\hline Variable & & $\begin{array}{c}\text { Male } \\
\mathbf{n}(\%)\end{array}$ & $\begin{array}{c}\text { Female } \\
\mathbf{n}(\%)\end{array}$ & $\begin{array}{c}\text { Chi-square } \\
\text { (p-value) }\end{array}$ \\
\hline $\begin{array}{l}\text { Biggest } \\
\text { worries in } \\
\text { life }\end{array}$ & $\begin{array}{l}\text { Financial } \\
\text { Problems }\end{array}$ & $\begin{array}{c}100 \\
(42.9)\end{array}$ & $\begin{array}{c}112 \\
(39.3)\end{array}$ & $\begin{array}{c}0.695 \\
(0.404)\end{array}$ \\
\cline { 2 - 5 } & Health & $\begin{array}{c}67 \\
(28.8)\end{array}$ & $\begin{array}{c}100 \\
(35.1)\end{array}$ & $\begin{array}{c}2.353 \\
(0.125)\end{array}$ \\
\hline $\begin{array}{l}\text { Most } \\
\text { feared } \\
\text { disabling } \\
\text { disease }\end{array}$ & Cancer & 79 & $\begin{array}{c}114 \\
(33.9)\end{array}$ & $\begin{array}{c}2.037 \\
(40.0)\end{array}$ \\
\cline { 2 - 5 } & $\begin{array}{l}\text { Alzheimer's } \\
\text { disease }\end{array}$ & $\begin{array}{c}45 \\
(19.3)\end{array}$ & $\begin{array}{c}72 \\
(25.3)\end{array}$ & $\begin{array}{c}2.595 \\
(0.107)\end{array}$ \\
\cline { 2 - 5 } & $\begin{array}{l}\text { Heart } \\
\text { disease }\end{array}$ & 59 & 40 & $10.564 * *$ \\
$(25.3)$ & $(14.0)$ & $(0.001)$ \\
\hline $\begin{array}{l}\text { Fears } \\
\text { regarding } \\
\text { having a } \\
\text { long-term } \\
\text { illness }\end{array}$ & $\begin{array}{l}\text { Being a } \\
\text { burden to } \\
\text { family }\end{array}$ & $\begin{array}{c}146 \\
(62.7)\end{array}$ & $\begin{array}{c}194 \\
(68.1)\end{array}$ & $\begin{array}{c}1.663 \\
(0.197)\end{array}$ \\
\cline { 2 - 5 } & $\begin{array}{l}\text { Using up } \\
\text { savings }\end{array}$ & $\begin{array}{c}32 \\
(13.7)\end{array}$ & $\begin{array}{c}39 \\
(13.7)\end{array}$ & $\begin{array}{c}0.000 \\
(0.987)\end{array}$ \\
\hline
\end{tabular}

** Significant level at $1 \%$

\section{Confidence on post retirement financial adequacy and comfort}

In this section, respondents were requested to state their confidence level relating to having sufficient money to live comfortably throughout their retirement years. Table 4 showed that about $52 \%$ of respondents were confident about having financial means to pull through old age, and there was no significant difference between male and female. Respondents were subsequently asked to state what they would do to ensure a comfortable retirement. The results indicated that for male respondents (57.5\%), reducing the cost of living upon retirement was the most preferred way, whereas, for the female, a majority (61.8\%) would rather increase savings and cut down on current expenses. However, a higher percentage of men (48.5\%) were willing to work longer while only $37.5 \%$ of women were willing to do so.

Table 4: Confidence on post retirement financial adequacy and comfort

\begin{tabular}{|l|l|c|c|c|}
\hline \multicolumn{2}{|l|}{ Variable } & $\begin{array}{c}\text { Male } \\
\mathbf{n}(\%)\end{array}$ & $\begin{array}{c}\text { Female } \\
\mathbf{n}(\%)\end{array}$ & $\begin{array}{c}\text { Chi- } \\
\text { square } \\
\text { (p-value) }\end{array}$ \\
\hline $\begin{array}{l}\text { Financial } \\
\text { adequacy }\end{array}$ & Confident & $\begin{array}{c}123 \\
(52.8)\end{array}$ & $\begin{array}{c}147 \\
(51.6)\end{array}$ & $\begin{array}{c}0.075 \\
(0.784)\end{array}$ \\
\hline $\begin{array}{l}\text { Ensuring } \\
\text { comfortable } \\
\text { retirement }\end{array}$ & $\begin{array}{l}\text { Increase } \\
\text { savings } \\
\text { by cutting } \\
\text { expenses } \\
\text { now }\end{array}$ & $\begin{array}{c}119 \\
(51.1)\end{array}$ & $\begin{array}{c}176 \\
(61.8)\end{array}$ & $\begin{array}{c}5.966^{*} \\
(0.015)\end{array}$ \\
\cline { 2 - 5 } & $\begin{array}{l}\text { Plan to } \\
\text { reduce } \\
\text { the cost of } \\
\text { living upon } \\
\text { retirement }\end{array}$ & $\begin{array}{c}134 \\
(57.5)\end{array}$ & $\begin{array}{c}155 \\
(54.4)\end{array}$ & $\begin{array}{c}0.507 \\
(0.476)\end{array}$ \\
\cline { 2 - 5 } & Work longer & 113 & 107 & $\begin{array}{l}6.296 * \\
(0.012)\end{array}$ \\
\hline
\end{tabular}

\section{Opinions on various dimensions of ageing and retirement}

The final section of the questionnaire requested the respondents to state how they felt or thought about the various dimensions of ageing and retirement. Table 5 showed that more than 80 per cent of the respondents agreed that they had a loving family, that they were leading a purposeful life, that they could still contribute to society, and that they would continue to have caring friends. More than 70 per cent agreed that they were financially independent. Women were significantly more positive than men about having a loving family. Interestingly too, significantly more women expressed their feeling of being financially independent as compared to men. A majority of the respondents stated that they would continue working as long as their mental and physical capabilities permitted and they would ideally like to live to at least 80 years of age. 63.2 per cent of female respondents would consider assisted living as compared to 56.2 per cent male, while 54.5 per cent male as compared to 48.1 per cent female respondents believed that they would not need long-term care at the age of 65 and beyond.

Table 5: Opinions on various dimensions of ageing and retirement

\begin{tabular}{|c|c|c|c|}
\hline Statement & $\begin{array}{c}* * \\
\text { Significant } \\
\text { level at } 1 \%\end{array}$ & $\begin{array}{c}\text { Female } \\
\mathrm{n}(\%)\end{array}$ & $\begin{array}{c}\text { Chi-square } \\
\text { (p-value) }\end{array}$ \\
\hline $\begin{array}{l}\text { I am leading a } \\
\text { purposeful life }\end{array}$ & $\begin{array}{c}202 \\
(86.7) \\
\end{array}$ & $\begin{array}{c}258 \\
(90.5) \\
\end{array}$ & $\begin{array}{c}1.892 \\
(0.169) \\
\end{array}$ \\
\hline $\begin{array}{l}\text { I have a loving } \\
\text { family }\end{array}$ & $\begin{array}{c}199 \\
(85.4) \\
\end{array}$ & $\begin{array}{c}263 \\
(92.3) \\
\end{array}$ & $\begin{array}{l}6.280 * \\
(0.012) \\
\end{array}$ \\
\hline $\begin{array}{l}\text { I continue to have } \\
\text { caring friends }\end{array}$ & $\begin{array}{c}191 \\
(82.0) \\
\end{array}$ & $\begin{array}{c}244 \\
(85.6) \\
\end{array}$ & $\begin{array}{c}1.262 \\
(0.261) \\
\end{array}$ \\
\hline $\begin{array}{l}\text { I am financially } \\
\text { independent }\end{array}$ & $\begin{array}{c}172 \\
(73.8) \\
\end{array}$ & $\begin{array}{c}232 \\
(81.4) \\
\end{array}$ & $\begin{array}{l}4.296 * \\
(0.038) \\
\end{array}$ \\
\hline $\begin{array}{l}\text { I can still contribute } \\
\text { to society }\end{array}$ & $\begin{array}{c}201 \\
(86.3) \\
\end{array}$ & $\begin{array}{c}248 \\
(87.0) \\
\end{array}$ & $\begin{array}{c}0.063 \\
(0.802) \\
\end{array}$ \\
\hline $\begin{array}{l}\text { I believe I will not } \\
\text { need long-term } \\
\text { care at age } 65 \text { and } \\
\text { beyond }\end{array}$ & $\begin{array}{c}127 \\
(54.5)\end{array}$ & $\begin{array}{c}137 \\
(48.1)\end{array}$ & $\begin{array}{l}2.125 \\
(0.145)\end{array}$ \\
\hline $\begin{array}{l}\text { I will continue } \\
\text { working as long } \\
\text { as my mental and } \\
\text { physical capability } \\
\text { permit }\end{array}$ & $\begin{array}{c}174 \\
(74.7)\end{array}$ & $\begin{array}{c}207 \\
(72.6)\end{array}$ & $\begin{array}{c}0.276 \\
(0.599)\end{array}$ \\
\hline $\begin{array}{l}\text { Ideally, I would like } \\
\text { to live to at least } 80 \\
\text { years }\end{array}$ & $\begin{array}{c}166 \\
(71.2)\end{array}$ & $\begin{array}{c}206 \\
(72.3)\end{array}$ & $\begin{array}{c}0.068 \\
(0.794)\end{array}$ \\
\hline \begin{tabular}{|l} 
I may consider \\
living in an assisted \\
living facility (e.g. \\
Retirement village)
\end{tabular} & $\begin{array}{c}131 \\
(56.2)\end{array}$ & $\begin{array}{c}180 \\
(63.2)\end{array}$ & $\begin{array}{c}2.570 \\
(0.109)\end{array}$ \\
\hline
\end{tabular}

$*$ Significant level at $5 \%$ 


\section{Discussion}

Interesting conclusions could be drawn from the results of the survey. Even though the respondents were of the opinion that most people in Malaysia would like to live up to the age of 81 years old, both male and female respondents felt that a man could only live up to 16 years past sixty. On the other hand, the male respondents reckoned that women would live longer, 18 years more past sixty, whereas female respondents showed more optimism, as they expected a woman to live 19 years more past sixty. The result was consistent with the contention of Ostan et al. (2015) that human longevity seemed strongly influenced by gender, defined as the combination between biological sexual characteristics of anatomy, reproductive functions, sex hormones and expression of genes, and the factors related to behaviour, social role, lifestyle and life experiences $(6,7)$.

When it came to concerns or worries in life, a larger percentage of women as compared to men, expressed health as one of the main factors. This could be because women expecting to live longer, had to face the inevitability of developing health problems in later life. This was in agreement with Pinquart, \& Sörensen (8) who revealed that despite striking difference in longevity, older women tended to have a more negative self-concept, expecting chronic health problems as they age, thereby resulting in the greater anxiety of their ageing process than men. The worries of women about health were reaffirmed further as could be seen from the significant difference with men, of fears of contracting Alzheimer's disease and arthritis and the thoughts of having to live with pain as they grow older (12). Women also showed a preference for an assisted living facility in order not to be a burden for the family. Although deciding so might be emotionally difficult, the preference for an assisted living would at least be temporary, until they regained their physical independence $(31,32)$.

In spite of the greater fears displayed by women relating to health, women displayed almost similar concern as the men on the financial resources and the cost of living, with similar levels of confidence on post-retirement comfort. This could be associated with the greater willingness of women to cut down their current expenses, to ensure a comfortable retirement, while men, on the other hand, were willing to work longer hours. This was consistent with the observations by Lusardi \& Mitchell (24), Kock \& Folk (20), Almenberg \& Säve-Söderbergh (22) and Shanmugam \& Zainal Abidin (21) that current financial resources had a strong positive impact on retirement preparedness. Also, a large majority of the working respondents stated that they would continue working for as long as their mental and physical capabilities permit.

\section{Conclusion}

There were varying views between men and women when it came to understanding ageing; about life expectancy, fears of ageing and deteriorating economic status and perception of old age comfort. Women were more optimistic about living longer as compared to men but feared more the consequences of diseases of old age. In spite of displaying less concern about financial preparedness, women were, however, willing to cut down on current expenses, while men would prefer to work longer to ensure financially secured ageing. In view that half of the respondents were willing to continue working for as long as their health permits, it is therefore imperative that policymakers understand how age structure and life expectancy of a population might have an impact on economic performance. An effective economic and public policy on labour supply, productivity, savings, social security, pension systems, healthcare insurance, expenditures and taxes, among others, is required.

\section{Acknowledgement}

The authors would like to acknowledge the support of the Population Studies Unit (PSU), Faculty of Economics \& Administration, University of Malaya for making this research possible.

\section{Declaration of Conflict of Interests}

The authors declare that there is no conflict of interest.

\section{Funding}

This research received no specific grant from any funding agency in the public, commercial or not-for-profit sectors.

\section{References}

1. Lubitz J, Cai L, Kramarow E, Lentzner H. Health, Life expectancy, and health care spending among the elderly. N Engl J Med. 2003; 349: 1048-1055.

2. Manton KG, Gu X, Lowrimore GR. Cohort changes in active life expectancy in the US elderly population: Experience from the 1982-2004 national long-term care survey. J Gerontol B Psychol Sci Soc Sci. 2008; 63 (5): S269-S281.

3. World Health Organization. (2015). World report on ageing and health. (pp.12-13).

4. Crimmins EM, Beltrán-Sánchez H. Mortality and morbidity trends: is there compression of morbidity? J Gerontol B Psychol Sci Soc Sci. 2011; 66(1): 75-86.

5. Ginter $E$, Simko V. Women live longer than men. Bratisl Lek Listy. 2013; 114(2): 45-49.

6. Ostan R, Monti D, Franceschi C. Gender and longevity. Ital J Gender-Specific Med. 2015; 1:10-14.

7. Regitz-Zagrosek, V. Sex and gender difference in health. EMBO reports 2012; 13(7):596-603.

8. Pinquart $M$, Sörensen S. Gender differences in selfconcept and psychological well-being in old age, a meta-analysis. J Gerontol B Psychol Sci Soc Sci. 2001; 56(4): 195-213.

9. Laditka JN, Laditka SB, Liu R, Price AE, Wu B, Friedman $D B$, et al. Older adults' concerns about cognitive health: commonalities and differences among six United States ethnic groups. Ageing Soc. 2011; 31: 1202-1228. 
10. Rashid A, Ong EK, Wong ESY. The attitude towards ageing among residents of an elderly care institution in Penang Malaysia. Int J Collab Res Intern Med Public Health. 2012; 4(6): 1069-1083.

11. Phillips WJ, Ferguson SJ. Self-compassion: A resource for positive ageing. J Gerontol B Psychol Sci Soc Sci. 2012; 68(4): 529-539.

12. Appelt CJ, Burant CJ, Siminoff LA, Kwoh CK, Ibrahim SA (2007). Arthritis-specific health beliefs related to ageing among older male patients with knee and/ or hip osteoarthritis. J Gerontol A Biol Sci Med Sci. 2007; 62:184-190.

13. Hayes A, Arima H, Woodward M, Chalmers J, Poulter $\mathrm{N}$, Hamet $\mathrm{P}$, et al. Changes in quality of life associated with complications of diabetes: results from the ADVANCE study. Value Health. 2016; 19(1): 36-41.

14. Laditka JN, Laditka SB. Increased hospitalisation risk for recently widowed older women and protective effects of social contacts. J Women Aging. 2003; 15(2-3): 7-28.

15. Clarke A, Warren L. Hopes, fears and expectations about the future: what do older people's stories tell us about active ageing? Aging Soc. 2007; 27(4): 465-488.

16. Bloom DE, Canning D, Fink G. Implications of population ageing for economic growth. Oxf Rev Econ Pol. 2010; 26(4): 583-612.

17. Hung A, Yoong J, Brown E. Empowering women through financial awareness and education.OECD working papers on finance, insurance and private pensions, No. 14, OECD Publishing. 2012. http:// dx.doi.org/10.1787/5k9d5v6kh56g-en

18. OECD, 2013 Report- Addressing women's need for financial education https://www.oecd.org/daf/fin/ financialeducation/OECD_INFE_women_FinEd2013. pdf

19. Yin-Fah BC, Masud J, Hamid TA, Paim L. Financial wellbeing of older peninsular Malaysians: A gender comparison. Asian J Soc Sci. 2010; 6(3): 58.

20. Kock H, Folk JY. Expected retirement age: $A$ determinant of financial planning preparation in Malaysia. Afr J Bus Manage. 2010; 5(22): 9370.

21. Shanmugam A, Zainal AF. Retirement confidence and preparedness: A study among working adults in a northern state in Malaysia. In Conference on Business Management Research 2013, December 11, 2013, EDC, Universiti Utara Malaysia, Sintok.

22. Almenberg J, Säve-Söderbergh J . Financial literacy and retirement planning in Sweden. J Pension Econ Financ. 2011; 10(4): 585-598.

23. Worthington AC. Predicting financial literacy in Australia. Financ Serv Rev. 2006;15: 59-79

24. Lusardi A, Mitchell OS. Planning and financial literacy: How do women fare?. Am Econ Rev. 2008; 98(2): 413-17.

25. Lusardi A. Numeracy, financial literacy, and financial decision-making.NBER Working Paper No.17821, Natl Bur Econ Res. 2012.
26. Noone J, O'Loughlin K, Kendig H. Australian baby boomers retiring 'early': Understanding the benefits of retirement preparation for involuntary and voluntary retirees. J Aging Stud. 2013; 27(3): 207-217.

27. Genworth Financial - Our family, our future: The heart of long-term care planning: A national examination by age wave. Sponsored by the Genworth Financial companies, November 2010 http://multivu.prnewswire.com/mnr/genwor thfinancial/43290/docs/43290-final-our_family_ourfuture112786_101210_gnw.pdf

28. Yin-Fah C, Paim L, Masud J, Hamid TA. The future of the Malaysian older employees: An exploratory study. IJBM. 2010: 5(4): 125-132.

29. Sim OF. Ageing in Malaysia: A review of national policies and programmes. In aging and long term care: National Policies in the Asia-Pacific. ISEAS, IDRC/2002: 107-149.

30. Bleidorn W, Arslan RC, Denissen JJ, Rentfrow PJ, Gebauer JE, Potter J, et al. Age and gender differences in self-esteem-A cross-cultural window. J Pers Soc Psychol. 2016; 111(3): $396-410$.

31. Saunders JC, Heliker D. Lessons learned from 5 women as they transition into assisted living. Geriatr Nurs. 2008; 29(6): 369-375.

32. Johnson R, Popejoy LL, Radina ME. Older adults' participation in nursing home placement decisions. Clin Nurs Res. 2010; 19(4): 358-375. 